\title{
SPEEDING THE PACE OF TECHNOLOGICAL DEVELOPMENT IN THE PETROLEUM INDUSTRY
}

$\mathrm{P}$ ERHAPS in no other branch of applied science has fundamental research, both in the field and in the laboratory, borne so much fruit in so short a time as that of petroleum technology. During the past thirty years, since the first World Petroleum Congress, the evolution of the industry has not only beon underlined by its magnitude and spectacular accomplishments but also by the complexity of the problems, both human and technical, that such rapid advancement of our knowledge of this technology has engendered. It is, indeed, timely that attention has been directed to the more philosophical aspects of the trend of modern research in the industry and its possible limitations if certain human factors are not taken into account. In no more appropriate setting than that of the sixth World Petroleum Congress held in Frankfurt during. June 19-26 could the facts and fears be proclaimed and few are better qualified than Mr. John Loudon, president of the Royal Dutch Petroleum Co. and senior managing director of the Royal Dutch/Shell Group of companies, to state the case as it really exists.

In his executive position in the industry and with all the experience he brings to bear, although he disclaimed at the outset of his address to the Congress: "any competence as an expert in science and technology", Mr. Loudon touched on some of the most sensitive aspects of planned research in the industry which have in recent years impressed themselves on the more far-seeing people concerned with guiding research teams and particularly with financing the adventures they are called on to undertake. For example, nobody could disagree with his contention ". . . that the limiting factor in science and technology is the number of creative individuals who provide the ideas from which all novelty comes". Again: "We have become so accustomed to thinking in terms of money and to assuming that more money will get us more of anything that is desired that we sometimes lose sight of other limitations. In research we may already have reached the state of diminishing returns for our investment -not only of industry but of society as a whole". Much has recently been heard of the lure of some of British topgrade scientists abroad, tempted by higher remuneration and alleged superior research facilities. But this competition is by no means confined to prospects overseas. The influence of Government Departments in Britain, quite apart from foreign interests, concerned with atomic energy, space research and national defence projects, for example, is felt in their ". . . competing for the limited available talent not only with industry and with universities but with each other". Mr. Loudon went on to say: "It is evident that much of the effort, both military and civilian, has been devoted not to really original concepts but to the rapid exploitation in many different laboratories of the few ideas that are occasionally produced by brilliant individuals".

The trend of policy of the Royal Dutch Petroleum Co. can be discerned from the statement that economically the profitability of industrial research, while still high, is decreasing due, apparently, to the increasing number of instances of simultaneous inventions; these complicate patent portfolios and render it difficult to decide whether money should be invested for projects based on technical novelty or superiority which could well turn out to be illusory. Much the same precepts, we suspect, are influential in the research policy of the other major oil companies at the present time. Thus, both the technical and economical difficulties ahead can, Mr. Loudon argued, only be solved by using available brainpower efficiently. "In our efforts to truly speed the pace of technology in the petroleum industry we must try to do two things: first, by supporting and undertaking basic research increase the number of new ideas; secondly, encourage our applied scientists and our commercial staff to be adventurous in their choice of new processes and products for development. And as citizens, we should ponder the question of whether the world can long afford an inefficient use of our previous asset of brainpower".

Only creative human talent can provide the science and technology needed to-day. That talent is limited, as is the case throughout the world. It is not enough to seek refuge in criticism of our present educational systems, on one hand deploring the fact that not enough scientists and technologists are being trained to meet the needs of our culture, or, alternatively, that science and technology are being over-stressed at the expense of the humanities, to the future detriment of that culture. Mr. Loudon concluded this most stimulating discourse with a statement of his belief ". . . that with a modicum of good sense and a minimum of dogma tho paradox (in the above opposing views) vanishes. Science and the humanities are by no means incompatible. ... In our business particularly, we need men trained in the sciences with an understanding of the humanities, men trained in the humanities with an understanding of science". Moreover, ". . the rare individuals who can master both worlds are those who are contributing most to the effective use of technology. Such men are also continuing to aid the universities, giving lectures, serving on advisory committees, sometimes even leaving us to take up permanent posts. And by prompt publication of our basic research we are contributing to the body of scientific knowledge". H. B. Munner

\section{THE INTERNATIONAL SCIENTIFIC RADIO UNION FOURTEENTH GENERAL ASSEMBLY}

\author{
By DR. R. L. SMITH-ROSE, C.B.E. (President)
}

$\mathrm{P}^{\mathrm{p}}$ REPARATIONS are now well in hand for the fourteenth general assembly of the International Scientific Radio Union (URSI) which will be held at the Takanawa Prince Hotel, Tokyo, during September 9-20. For the past two years a large committee, appointed by the Science Council of Japan, has been preparing the general arrangements under the guidance of a smaller Executive Board, of which Prof. I. Koga, vice-president of the Intornational
Scientific Radio Union, is the chairman, and Prof. S. Okamura the secretary. The detailed programme for the assembly is being organized by six small committees including two doaling with tho scientific and ladies programmes respectvely.

The fortheoming general assembly is noteworthy in that it will mark the fiftieth anniversary of the formation of the International Scientific Radio Union at a small 
preliminary meeting in Brussels attended by nine scientists during October 1913. A second meeting was held during April 1914, and was attended by fourteen scientists from six European countries. After the First World War the Union was one of the first to be organized in 1919 under the general supervision of the International Research Council, which in 1931 was replaced by the International Council of Scientific Unions. The other three Unions were the International Astronomical Union, the Union of Geodesy and Geophysics and the Union of Pure and Applied Physics.

The first General Assembly of the International Scientific Radio Union was held in Brussels in 1922, and was followed by others in Washington (1927), Brussels (1928), Copenhagen (1931), London (1934) and Venice (1938). After an interval during the Second World War, the activities of the Union were resumed at the seventh general assembly held in Paris in 1946; and this was followed at two-year intervals by meetings in Stockholm, Zurich, Sydney and The Hague until 1954. On the last occasion it was decidod to change the interval between assemblies to three years; and the twelfth and thirteonth were held in Boulder and London in 1957 and 1960 respectively. The attendance on the latter occasion was about 830 , of whom nearly 450 were official delegates, and 150 were observers from the host country interested in various aspects of the scientific programme. There were also a small number of invited guests, and some 200 members of the families of delegates and observers.

The International Scientific Radio Union is one of the fifteen scientific bodies which now adhere to the International Council of Scientific Unions and it is in effect a federation of the national scientific academies in 28 countries throughout the world. The objectives of the Union are to promote and organize radio research requiring international co-operation, to encourage the development of such agreed methods of measurements as may be required for the investigation of any radio phenomona with particular reference to those associated with the Earth, its atmosphere and outer space. The influence of the Sun and of general and geophysical conditions on the radio phenomena has naturally required close collaboration between the four Unions referred to here. In more recent years, this collaboration has been extended to include the International Committee on Space Research (COSPAR) which was formed in 1958 and has recently held its fourth international symposium in Warsaw (May $1963)$.

To return to the forthcoming general assembly of the International Scientific Radio Union, the seiontific programme is being organized under the existing seven commissions, the titles and present chairmen of which are: (1) radio standards and measurements methods
(Dr. U. Adelsberger); (2) radio and troposphere (Mr. J. Voge); (3) ionospheric radio (Mr. J. A. Ratcliffe); (4) radio noise of terrestrial origin (Prof. R. A. Helliwell); (5) radio astronomy (Sir Bernard Lovell); (6) radio waves and circuits (Mr. J. Loela); (7) radioelectronics (Prof. W. G. Shepherd).

The wide range of scientific activities in various parts of the world in most, if not all, the aforementioned fields has made it necessary to restrict the scope of the items selected for discussion at each of the sessions which will be available to the commissions. Accordingly, each chairman has formulated the subjects to be discussed by his commission and has invited some well-known authorities to prepare introductory papers for presentation at Tokyo. These papers, together with a summary of the main features of the discussion thereon, will be published in the Proceedings of the general assembly. In accordance with past practice, no uninvited papers will be considered for acceptance. As some of the subjects selected for discussion are of common interest to more than one commission, arrangements have been made in the programme for joint meetings and also for meetings of the commissions with other committees of the Union such as that on space radio research or with the International Committee on Geophysics. The latter body, incidentally, has replaced the former committee which organized the co-operative scientific work during the International Geophysical Year of 1957-58 and afterwards, and it has recently been actively engaged in formulating the corresponding programme for IQSY, the International Year of the Quiet Sun (1964-65).

At the general assembly in London in 1960, representatives from the International Scientific Radio Union were appointed to its parent body-ICSU-as well as to various specialist committees in which the Union is associated with the interests of other unions or committees in such subjects as the ionosphere, radio meteorology, solar and terrestrial relationships, space researeh and the allocation of radio frequencies for radio astronomy and space science. In this way, full collaboration is maintained between scientists in all parts of the world engaged in research in adjacent fields concerned with the Earth and its atmosphere, the Sun, the planets and outer space. Meotings of these committees will be called as may be appropriate during the general assembly, taking advantage of the presence in Tokyo of the various interested scientists.

During the Assembly various formal receptions are being arranged by the Japanese Committee, and some visits of technical interest will be offered to the visitors. A special programme for ladies has also been distributed. After the assembly, a four-day tour is available to Kyoto and Nara, towns which are of historic interest because they were former capitals of Japan.

\section{MULTIPLE MOLECULAR FORMS OF ENZYMES AND THEIR USE IN CLINICAL DIAGNOSIS}

\begin{abstract}
A SYMPOSIUM on "Multiple Molecular Forms of A Enzymes" organized by the University of Ghent in collaboration with the Belgian Society for Clinical Chemistry, was held in Ghent on April 27. It was the first of its kind in Europe, and the interest it arose can be judged from the fact that several weeks before the deadline for registration, the limiting number of 150 participants had already been reached. Representatives from most west European countries were included among the speakers and also several from the United States.

The meeting was concerned with the structure of isoenzymes and with their clinical uses. As to the first, E. Appella (Centre de Chimie Macromoléculaire, Strasbourg) presented data defining the physical properties of lactic
\end{abstract}

dehydrogenase 1 (LDH1) and LDH5 (beef tissue) and their amino-acid composition. All available evidence tends to support the hypothesis formulated by the author together with Markert that LDHI is composed of four identical sub-units, while LDH5 is composed of four identical sub-units of another type; LDH2, LDH3 and LDH4 correspond to combinations of each of these sub-units into groups of four. These hybrid forms can be produced in vitro: following dissociation into sub-units of pure LDHI and LDH5 molecules in a medium of high ionic strength, randomized re-association occurs on removal of the sodium chloride.

M. D. Poulik (Child Research Center, Detroit) took ceruloplasmin as an example of a second class of isoenzymes 